\title{
Pregnancy and childbirth: What changes in the lifestyle of women who become mothers?
}

\author{
GRAVIDEZ E PARTO: O QUE MUDA NO ESTILO DE VIDA DAS MULHERES QUE SE \\ TORNAM MÃES?
}

\author{
EL EMBARAZO Y EL PARTO: ¿QUÉ CAMBIOS EN EL ESTILO DE VIDA DE LAS \\ MUJERES QUE SON MADRES?
}

\section{Emília de Carvalho Coutinho1, Cristina Bastos da Silva², Cláudia Margarida Balula Chaves ${ }^{3}$, Paula Alexandra Batista Nelas ${ }^{4}$, Vitória Barros Castro Parreira ${ }^{5}$, Maria Odete Amaral 6, João Carvalho Duarte ${ }^{7}$}

\begin{abstract}
Pregnancy is a period influenced by the interaction of several factors, therefore this study aimed to identify changes in lifestyles due to pregnancy and childbirth in Portuguese and immigrant women in Portugal. This is a qualitative study, using the semi-structured interview, with eightytwo Portuguese and immigrant women. Content analysis was used, with verbatim classification supported by Nvivo 10. It was authorized by an Ethics Commission. Results revealed that the primary changes in lifestyles due to pregnancy were in eating habits (nutrition), daily activity, exposure to danger, sleep and rest patterns, social and family relationships, going out, selfcare, work, clothing and footwear, travel, health monitoring and sexual activity and substances consumption. The main change after the birth, manifested by these women, was that their lives began to revolve around their baby.
\end{abstract}

DESCRIPTORS
Pregnancy
Lifestyle
Change
Childbirth

\section{RESUMO}

O decurso da gravidez é determinado pela interação de diversos fatores, pelo que este estudo teve como objetivo conhecer as mudanças nos estilos de vida provocadas pela gravidez e pelo parto em mulheres imigrantes e portuguesas. Estudo de natureza qualitativa, exploratório, que recorreu à entrevista semiestruturada, em oitenta e duas mulheres imigrantes e portuguesas. Foi utilizada a análise de conteúdo com a categorização do verbatim suportada pelo Nvivo 10. O estudo foi autorizado por uma Comissão de Ética. Os resultados apontaram como principais mudanças ocorridas nos estilos de vida, provocadas pela gravidez, as relacionadas com a alimentação, atividade diária, exposição a perigos, sono e repouso, relações sociais e familiares, saídas, cuidado consigo própria, trabalho, vestuário e calçado, viagens, vigilância de saúde, vivências da sexualidade, e consumos. A principal mudança, após o parto, manifestada por estas mulheres, foi que a sua vida passou a ser gerida em função do bebé.

DESCRITORES
Gravidez
Estilo de vida
Mudança
Parto

\section{RESUMEN}

El desarrollo del embarazo está determinado por la interacción entre varios factores. En este estudio fueron evaluados los cambios en el estilo de vida causadas por el embarazo y el parto en mujeres inmigrantes y portuguesas. El estudio posee un carácter cualitativo y exploratorio recurrió a entrevistas semiestructuradas, en ochenta y dos mujeres inmigrantes e portuguesas. Se utilizó el análisis de contenido apoyado por el programa QSR Nvivo10El estudio fue aprobado por un Comité de Ética. Los resultados mostraron cómo grandes cambios en los estilos de vida causados por el embarazo, relacionados con la alimentación, la actividad diaria, la exposición a riesgos, el sueño, el descanso, las relaciones sociales y familiares, salidas, cuidar de sí misma, el trabajo, la ropa y el calzado, viajes, vigilancia de la salud, las experiencias de la sexualidad y el consumo. El principal cambio, después de la entrega, que se manifiesta por estas mujeres, era que su vida tiene que ser manejado de acuerdo a la bebé.

DESCRIPTORES
Embarazo
Estilo de vida
Cambio
Parto

${ }^{1} \mathrm{PhD}$ in Nursing Sciences, School of Health of Viseu IPV/CIDETS, Viseu, Portugal. ${ }^{2}$ Nurse, currently unaffiliated, Viseu, Portugal. ${ }^{3}$ PhD in Education Sciences, School of Health of Viseu IPV/CIDETS, Viseu, Portugal. ${ }^{4} \mathrm{PhD}$ in Education Sciences, School of Health of Viseu IPV/CIDETS, Viseu, Portugal. ${ }^{5}$ Master in Nursing Sciences, School of Nursing of Porto, Portugal. ${ }^{6}$ PhD in Public Health, School of Health of Viseu IPV/CIDETS. Viseu, Portugal. ${ }^{7}$ PhD in Mental Health, School of Health of Viseu IPV/CIDETS, Viseu, Portugal. 


\section{INTRODUCTION}

Pregnancy is a requirement for the survival of human life, being essential to the generational renewal, and represents the period of formation of a new being. This starts with the conception, extends over a period of about 40 weeks, and ends with the delivery ${ }^{(1)}$. It is a period of profound changes, concerning lifestyle, not only in the personal life, but also in the lives of the couple and the whole family. This is a stage of physical and psychological preparation for birth and parenting ${ }^{(2)}$.

Studies reveal that physiological changes occurring during pregnancy result in increased nutritional needs of the pregnant women, which, although similar to those of non-pregnant women have some particularities regarding the need for energy, protein, certain vitamins such as thiamine, folic acid, vitamin C, and minerals such as iron, zinc, copper and magnesium ${ }^{(3)}$.

It is also common knowledge that although physical exercise is an increasingly present practice in everyday life, due to the growing worldwide awareness of healthy lifestyles, and although pregnancy is not illness, it is, however, a period that involves several changes in the maternal body, so that physical exercise should be balanced and take into account the woman's habits before the pregnancy. On one hand, the practice of physical activity can lead to the risk of hypoglycaemia, hyperthermia, decreased blood flow to the placenta, and musculoskeletal injuries, on the other, it also has health benefits such as improving body fat control, promote psychosocial interactions, and the eventual facilitation of labour ${ }^{(4)}$. Hence physical exercise should be of low intensity and the average duration should be forty minutes not to cause complications for the mother and the foetus ${ }^{(4)}$.

Studies also relate that consumption of harmful substances such as tobacco and alcohol, and exposure to polluted environments is detrimental to the general population and pregnant women, due to the phase they are going through, are no exception.

Since pregnancy is a time of intense physical and psychological changes in women's lives, it can and should be an opportunity to adopt healthier life styles ${ }^{(5)}$.

Literature denotes that sexuality is one of the most natural characteristics of being human ${ }^{(6)}$; it is a biological, physiological reality and one of the engines of human existence.

In this framework, considering the changes in lifestyles presented, the birth of a child marks the lives of women and the family as a period filled with changes and with enormous impact on their individual and family lives. The pregnant woman, in addition to having to adapt to physical changes caused by childbirth, is now faced with a new being that depends on her.
Considering the context presented, this study aimed to identify changes in lifestyles due to pregnancy and childbirth in Portuguese and immigrant women in Portugal.

\section{METHOD}

This is qualitative research study, using semi-structured interviews for data collection. Content analysis of verbatim interviews was done resorting to the Qualitative Analyses Software Certified Partner (NVivo version 10). The study abided by the ethical principles with the study participants, the institutions involved and the $\mathrm{Na-}$ tional Commission for Data Protection (Case 85/2011, No. 191/2011). The interviews took place in the period between February 2011 and February 2012, with the use of the recording and subsequent transcription of verbatim.

The study population consists of Portuguese and immigrant women in Portugal, recent (less than a year) mothers, from two districts of the Central Region of Portugal. The sample comprises of 82 women, 22 of which are Portuguese and 60 are immigrants. In this sample 22 nationalities are represented, with $28.05 \%$ Portuguese women, $17.07 \%$ Brazilian, $13.41 \%$ Ukrainian, $9.76 \%$ Chinese, $4.88 \%$ Moldovan, 3.66\% French, $3.66 \%$ Russian, $2.44 \%$, Spanish, $2.44 \%$ Indian, and $1.22 \%$ of each of the other nationalities. Inclusion criteria were: to be Portuguese or Immigrant in Portugal, to be a recent mother (less than a year); knowledge of the Portuguese language, and acceptance to participate in the study.

Table 1 - Socio-demographic characterization of the sample

\begin{tabular}{cc}
\hline & $\mathbf{N}=\mathbf{8 2}$ \\
\hline Age Group & 1 \\
$<21$ & 61 \\
$21-35$ & 20 \\
$>35$ & \\
Marital status & 69 \\
married/de facto union & 13 \\
Single/divorced/widow & \\
\hline Academic Qualifications & 19 \\
$\leq 9^{\circ}$ grade & 20 \\
10-12 ${ }^{\circ}$ grades & 43 \\
Higher Education & \\
\hline Professional status & 63 \\
Employed & 19 \\
Unemployed & \\
\hline
\end{tabular}

Figure 1 represents the sample in terms of number of pregnancies.
Pregnancy and childbirth: What changes in the lifestyle of women who become mothers Coutinho EC, Silva CB, Chaves CMB, Nelas PAB, Parreira VBC, Amaral MO, Duarte JC 


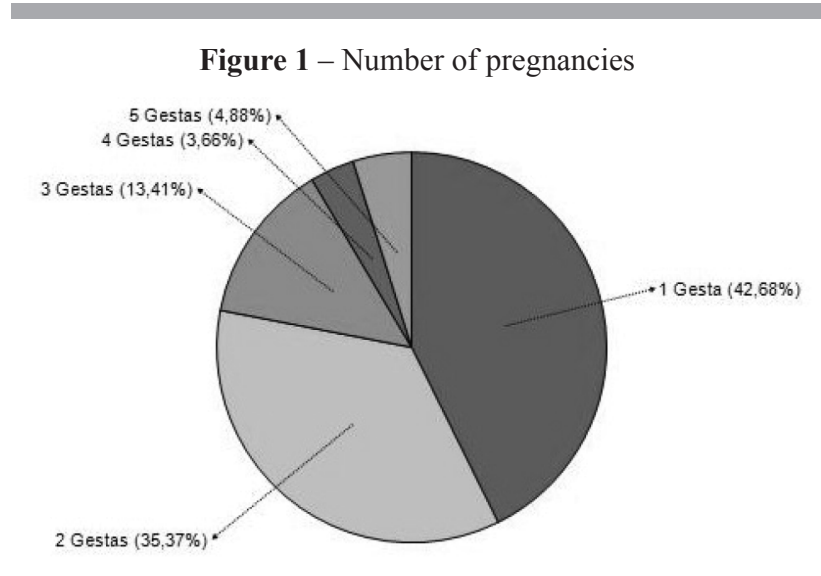

\section{RESULTS}

To achieve the goal defined in the introduction, the study was developed in order to bring out the changes in lifestyles due to pregnancy and childbirth in Portuguese and immigrant women.

In this sense, the emerging results of the analysis and the coding of verbatim provided by the participants' interviews are presented below; these reflect what the participants believe are changes in their lifestyles caused by pregnancy and childbirth. One can observe, from Table 2, that pregnancy caused some changes in several domains "Changes due to the pregnancy were many, I was used to being very independent and to do whatever I felt like doing... now normal day-to-day activity is all changed, from going on holidays, concerts and even walking. I wasn't able to stand up for long periods of time, everything I did had to be done with the limitations I had "(AN France).

The key domains evidenced by exposure of some of the participants' speech are presented in table 2 .

Table 2 - Changes in lifestyles caused by pregnancy

\begin{tabular}{cc}
\hline Category & Subcategory \\
\hline & Eating habits \\
Daily activity \\
Exposure to danger \\
Sleep and rest Schedules \\
Family relations \\
Changes in lifestyles & Going out \\
caused by pregnancy & Self-care \\
& Work \\
& Clothes and footwear \\
& Travels \\
& Health Monitoring \\
& Sexual activity \\
\hline
\end{tabular}

Therefore, as for the eating habits, this change is revealed, on the one hand, in the wishes of the pregnant woman and on the other hand, the concern with healthy eating for both mother and child
"... I had an addiction to drinking coke during pregnancy" (CP Brazil);

"...during pregnancy I was careful to eat everything well washed, and have a healthy diet" (AO Congo);

"I ate more fish during pregnancy" (AE Brazil);

"With the pregnancy I ate more fruit" (CN Moldova);

"I started eating more vegetables in pregnancy" (AC Ukraine);

"I never drank milk and started drinking it after becoming pregnant; I started to eat more yogurt" (DA Ukraine);

"I cut a lot in fats and fried food" (AE Brazil);

"I began drinking plenty of water during pregnancy" (BT Romania).

There were also changes in daily activity which became more moderate, as evidenced by the participants' speech.

"I was unable to make great exertions during pregnancy, I used to go hiking but not for long, I used to do it for approximately 30 minutes per day" (BG Portugal);

"With the pregnancy I stopped doing a number of things: stopped doing impact sports, stopped doing a lot of things ... I stopped doing sports ..." (CH Portugal).

The exposure to hazards was safeguarded during pregnancy, either with regard to the consumption of tobacco and alcohol, as well as contact with polluted environments.

"I used to smoke before, I no longer smoke, and did not smoke during pregnancy", (Cl Brazil);

"... with the pregnancy I stopped drinking alcohol, I really had to do it, because it could harm the baby" (DA Ukraine);

"During pregnancy even though I wanted to go out at night ... not to the places where I used to go: there could be smoke... (CE Portugal).

The women also felt a need to regulate the sleep and rest patterns, due to the new condition.

"I slept much, much more during pregnancy" (BY Poland);

"With pregnancy I changed in terms of rest, basically when I was pregnant I was very sleepy, I slept a lot..."(CQ China).

Social and family relationships became different with pregnancy, there is a greater marital closeness.

“... me and my husband, we've become much better friends. Our relationship became much closer than when I was not pregnant"(CZ Brazil);

"We became closer to the family with the pregnancy"(CU India).

Additionally, there was a change regarding going out, which no longer happened in some pregnant women lives, while in others was significantly reduced. 
"With the pregnancy one has to give up going out" (CQ China);

"When I was pregnant I did not go out" (BI Portugal).

With the pregnancy the woman started to be more careful with herself, adopting healthier habits for her and the baby.

"...pregnancy was what led me to... a healthier life for me and for her "(AT Argentina);

"I had more care with me during pregnancy" (BQ Moldova)

The condition of pregnancy, and inherent discomforts, also conditioned work performance.

"he put it like this, well if you already feel a lot of pain in the back and belly, talk to the person in charge and she will arrange a person for the section, to do your work "(CL Portugal);

"I stopped working... once I was at work, and started to bleed... I could not stand anymore, although my boss said that I still had a small belly, and I could work "(BJ Portugal);

"I stopped working because I was pregnant" (AC Ukraine).

Likewise, there was a need to adjust the clothing and footwear to the new condition of pregnancy and new body as demonstrated in the participants' speech.

"I started using more comfortable and larger clothes during pregnancy" (AC Ukraine);

"... at the end of pregnancy I was wearing slippers, because I could no longer wear the rest" (BH Portugal).

Furthermore pregnancy limited the travels by the participants.

"With the pregnancy I could not do long trips" (AV Portugal).

It is evident, in the participants' speech, the change that occurred in the frequency of health monitoring, which use to be yearly, and changed into monthly, at the very least.

"Before getting pregnant I only went to the doctor once a year ... but after the pregnancy I always went, every month"(Cape Verde DD).

During pregnancy, sexual activity assumed different forms, either by sexual abstinence, adoption of new strategies due to the size of the belly, or even changed the libidinal impulses and exacerbation of sexual desires.

"My husband was a little scared of the belly ... and forgot it"(CJ Portugal);

"In sexual relations ... sought more appropriate positions" (BC Portugal);

"... near the end ... there began an appetite out of the ordinary ... I woke up in the night and just felt like waking him ..."(CL Portugal).
As demonstrated in Table 3, there were several changes in lifestyles after giving birth reported by the women interviewed.

Table 3 - Changes in lifestyle after childbirth

\begin{tabular}{ll}
\hline Category & Subcategory \\
\hline & there's no longer a me, there's us \\
& greater responsibility for what one eats and drinks \\
& Changes of the marital relationship \\
Changes in & losing the freedom to go out \\
lifestyle after & having to wake up often during the night; \\
childbirth & $\begin{array}{l}\text { have more domestic tasks } \\
\text { having to change professional occupation } \\
\text { having to manage one's life revolving around the baby }\end{array}$ \\
\hline
\end{tabular}

Among these changes, the figure of "me" is replaced by "us", as highlighted by the speech of some participants.

"With the birth of the baby...there is no longer a "me", there is "us". (CH Portugal).

It also emerged a greater responsibility for what one eats and drinks and with the quality of their milk.

"I'm trying to eat some foods that I did not eat before, because of the baby, ... so that the breast milk has the necessary nutrients for the baby I try to eat more and I think of what foods I should eat "(CB Ethiopia).

After the birth, changes occur in the marital relationship.

"With the pregnancy and also now the relationship between the couple changed. Now it's different!" (AT Argentina).

The feeling of losing the freedom to go out is also reported;

"When I didn't have a baby I could go out, I could go for a walk, now I have to be closer to the baby. (AK Russia)";

And the need of having to wake up often during the night is also expressed, as a change of lifestyle.

"Now I have to wake up at night to care for the baby" (CB Ethiopia);

"We had to feed every two hours at night ... more than two weeks every two hours ... it was hard!" (CD Netherlands).

The increase of domestic activities is also expressed.

"With pregnancy and childbirth more housework accumulated, a little more work, I have to divide myself in another part, because we are already three at home" (BZ Moldova).

Again there is a need of having to change the professional activity, with the family being the main centre of interest.

"Before the baby was born, I was a person very focused on professional activity, now everything stopped” (AN France);
Pregnancy and childbirth: What changes in the lifestyle of women who become mothers

Coutinho EC, Silva CB, Chaves CMB, Nelas PAB, Parreira VBC

Amaral MO, Duarte JC 
"With the birth of baby I stopped working [to be with the baby] because I don't feel right sending a 4 to 6 months child to daycare" (AZ Ukraine).

In the last subcategory participants are confronted with the necessity of having to manage life depending on the baby

\section{"After birth, (of the baby) it is completely different" (CH Por- tugal)}

"Now with the birth of the baby everything is different, everything is in function of her" (AV Portugal).

\section{DISCUSSION}

From the data analysis emerged changes in lifestyle caused by pregnancy and childbirth caused by

As regards the changes in lifestyles caused by pregnancy, although 11 (13.41\%) women stated that there were no changes in his style of life during pregnancy, $15(18.29 \%)$ reported that the changes were many, 50 (60.98\%) reported changes in their eating habits, 14 (17.07\%) reported having felt differences in daily activity , 12 (14.63\%) reported avoiding dangers during pregnancy, $6(7.32 \%)$ showed differences in the sleep and rest patterns, $5(6.09 \%)$ reported changes in social and family relationships, $3(3,66 \%)$ had stressed more restrictions on going out, 7 (8.54\%) reported having more self-care, $14(17.07 \%)$ reported changes in relation to work, 21 (25.61\%) have referred changes in clothing and footwear, $12(14.63 \%)$ reported changes in health monitoring and $28(31.15 \%)$ mention changes in sexual activity. Several authors highlight pregnancy as a period of transition and change ${ }^{(7)}$, corroborating the present results.

It is important to stress the importance of having a balanced, complete and varied diet to meet nutritional needs. Although 3 (3.66\%) of respondents said they eat less well, $24(29.27 \%)$ participants reported paying more attention their eating habits. The responses of $23(28.05 \%)$ women were grouped according to the New Food Wheel since they were in accordance with the recommendations given by the Portuguese Directorate General of Health. One can observe an increased consumption of meat, fish and seafood reported by 9 (10.97\%) women; with an increased consumption of fruit were 3 (3.66\%) women and of vegetables and dairy. Also 5 (6.09\%) women reported lower consumption of fats and oils, and some people referred increased water consumption. Physiological changes occurring during pregnancy determine an increase in the nutritional needs of the pregnant women, which, although similar to those of non-pregnant women have some particularities regarding the need for energy, protein, certain vitamins such as thiamine, folic acid, vitamin $\mathrm{C}$, and minerals such as iron, zinc, copper and magnesium ${ }^{(3)}$, as referred in some studies.

The results obtained reveal that most women who described changes in daily activities, reduced the exercise, but few stopped it entirely, with none reporting doing intense physical exercise during the pregnancy and the ones who did before, stopped it. There is also literature on this subject as there are growing numbers of women who practice physical exercise during pregnancy. Although pregnancy is not a disease nor a disability, it is a period that involves many changes in the maternal body and physical activity can lead to risks as hypoglycaemia, hyperthermia, and musculoskeletal injuries, decrease blood flow to the placenta, as well as hypoglycaemia and hyperthermia in the foetus, but also has benefits such as better control of body fat, psychosocial interactions and possible facilitation of labour, due to an improved blood circulation, enhancement of muscle balance; reduced swelling, relief of bowel discomfort, decrease leg cramps, strengthening abdominal muscles and ease the postpartum recovery. Therefore, authors recommend low intensity exercise and of an average duration forty minutes not to cause complications for the mother and the foetus( ${ }^{(4)}$. Women who get fatter during the first half of pregnancy are more likely to give birth to an obese baby ${ }^{(8)}$. More recent studies have confirmed that the practice of about twenty minutes of moderate and regular exercise during pregnancy improves brain development in new-borns ${ }^{(9)}$.

The consumption of harmful substances such as tobacco and alcohol, and exposure to polluted environments is detrimental to the general population and pregnant women, due to phase they are going through are no exception. In our study, 11 (13.41\%) participants avoided exposure to hazards, including smoking cessation, stop consuming alcohol and avoid polluted environments. For these women, the change occurred in their lifestyle was due to the fact that they were pregnant and the objective was the wish to reduce the risk to the baby. This adoption of healthier life styles is also present in the speech of 7 (8.54\%) women who reported that during pregnancy had more care about themselves. These results are corroborated by other studies, in that tobacco use is still considered the main cause of preventable morbidity and mortality in developed countries, as well as a major public health problem globally, with effects on the reproductive function and development of a healthy pregnancy ${ }^{(8)}$. Authors also refer that the consumption of alcohol during the first trimester of pregnancy has been associated with increased risk of foetal malformations ${ }^{(10)}$. In agreement with the results of the present study, other studies confirm that, since pregnancy is a time of profound physical and psychological changes in women's lives, it can and should also be an opportunity to adopt healthier life styles ${ }^{(5)}$.

According to the results obtained, 12 (14.63\%) women conveyed having amplified health monitoring during pregnancy. As mentioned in a previous study ${ }^{(11)}$, pregnancy involves risks for the mother and the new-born, but vigilance and adequate provision of antenatal care, allows for a favourable clinical outcome. The decrease in maternal and foetal morbidity depends, among other things, on a proper planning and monitoring of pregnancy. 
Traveling is not inadvisable for low risk pregnant women, however results in this study reveal that $4(4.88 \%)$ women reported avoiding travels. As stated in the literature, pregnant women who plan to make long trips should organise periods of activity and rest; if they are driving they should stop every hour and wear a seat belt ${ }^{(12)}$.

Sleep and rest, being basic human needs, are essential to life, and these needs during pregnancy are amplified. In this study, 6 (7.32\%) participants reported changes of sleeping habits, namely that they slept more during pregnancy. A pregnant woman is advised to plan regular rest periods, especially as the pregnancy progresses, because she is more easily tired, ending up to restricting her outings.

As for changes in the family relationships, these are documented by 5 (6.10\%) participants in the study, in harmony with the stated by other authors who refer that pregnancy is an important event in the experiences of all family members, reflected in the family structure and in the creation of emotional bonds among its members, and despite the intense changes in the structure and organization of the family; this remains a unit that takes care of its members ${ }^{(13)}$. In this context, the job of the companion changes, as during pregnancy, his main role is to accept and respond to feelings of vulnerability of the pregnant woman ${ }^{(14)}$.

As for work related changes, some authors consider that the work done on the job does not normally cause adverse effects on gestation outcomes, and suspension of the labour activity is usually due excessive fatigue ${ }^{(15)}$. In this study 5 (6.10\%) women referred other causes to decrease or abandon work, as obstetric complications and medical advice; 2 (2.24\%) women reduced work by choice and $2(2.24 \%)$ stopped working due to being pregnant.

The physical changes inherent to pregnancy lead the women to adapt their clothing. It should be noted that most women who conveyed having felt changes on clothing and footwear choices, testified to have changed to more comfortable and loose clothing, and wider and low heel footwear. As confirmed by other authors, comfortable and loose clothing is the most suitable for pregnant women, to prevent some complications and provide greater comfort; it is advisable to use comfortable shoes with good stability and fostering good body posture(16).

As for sexuality, this is one of the most natural characteristics of being human ${ }^{(6)}$. In this study there was one woman who reported having increased sexual activity towards the end of pregnancy; compatible to the acknowledged sexual desire due to increased libido in late pregnancy. Sexuality is a biological, physiological reality and one of the engines of our existence. Addressing sexual intercourse during pregnancy is essential, and if once it was prohibited during pregnancy, nowadays it is encouraged in view of the wellbeing of the couple. In the early period of pregnancy it is frequent the occurrence of emotional vulnerability along with physical changes such as nausea, vomiting, drowsiness, tired- ness making the woman feel less sexual appetite; however demonstrations of affection and care from the father ${ }^{(17)}$ are welcome. In late pregnancy, if some couples increase their sexual activity, other couples are more reluctant to seek it, some even abstain since the discomfort is increased due to tiredness, fatigue, and awkwardness because of the bel${ } y^{(18)}$. Despite the knowledge evolution in this area there are still myths, beliefs, moral and cultural values of the sexuality experiences in the context of pregnancy ${ }^{(18)}$.

As for changes in lifestyle after childbirth, 14 (17.07\%) women described that after the birth of the baby, everything is managed around the child. This is validated by some authors, in the sense that The birth of a baby is a period marked by many changes and has huge impact on personal and family life of individuals; women as well as having to adapt to physical changes caused by childbirth, are faced with a new being which depends on them. The birth of a child constitutes a change in the existing inter-relational structure in a family ${ }^{(19)}$.

In a country where the birth rate is so low, it is worth noting that for three-fifths of the sample it was not their first experience of motherhood which to some extent results in differences in awareness for each woman, in how they face and live these changes.

\section{CONCLUSION}

This study aimed to know the changes in lifestyles due to pregnancy and childbirth in Portuguese and immigrant women in Portugal. Most women adopted healthier lifestyles during pregnancy, considering both themselves and the baby, and used this period to put aside some less healthy habits, as is the case of tobacco, alcohol and exposure to polluted environments.

The results showed that major changes in lifestyles due to pregnancy were in eating habits, they became more careful, in daily activity, which became more moderate; in exposure to hazards, which was avoided; sleep and rest sought by the women; in social and family relationships, that became closer; going out patterns, which were reduced or even avoided; self-care, which increased; at work, where there was a need to slow down or sometimes stop; in clothing and footwear, adjusted, for comfort to the condition of pregnancy; on journeys, which were diminished or even avoided; Health surveillance, which was significantly increased; and the experiences of sexuality, where new strategies were sought to adapt to the circumstances.

The main changes experienced by these women, after childbirth, were that they lives came to be managed in the light of the baby, in this sense, outings, domestic activity, work, sleep and rest, are conditioned by the baby's schedule, since the baby always comes first and is the centre of attention.

Limitations of this study, one has to point out the largest number of immigrant pregnant women in relation to the Portuguese; the fact that not enough published stud-
Pregnancy and childbirth: What changes in the lifestyle of women who become mothers

Coutinho EC, Silva CB, Chaves CMB, Nelas PAB, Parreira VBC

Amaral MO, Duarte JC 
ies were found that focused on this subject of the Portuguese and immigrant population in Portugal, precluding further discussion on it.

Considering our results, no significant differences were found in lifestyles between Portuguese and immigrants who experience the process of motherhood, taking into account their culture, but only with regard to their condition of becoming a mother; however one suggests the development of other studies with Portuguese immigrants and pregnant around this issue, due to lack of existing literature.

\section{REFERENCES}

1. Council AHMA. Clinical Practice Guidelines: Antenatal Care Module I. Canberra: Australian Government Department of Health and Ageing; 2012.

2. Mendes IM. Ajustamento materno e paterno: experiências vivenciadas pelos pais no pós parto. Coimbra: Mar da Palavra; 2009.

3. Blumfield ML, Hure AJ, Macdonald-Wicks L, Smith R, Collins CE. A systematic review and meta-analysis of micronutrient intakes during pregnancy in developed countries. Nutrition Reviews. 2013;71(2):118-32. PubMed PMID: 23356639.

4. Petrov Fieril K, Fagevik Olsén M, Glantz A, Larsson M. Experiences of Exercise During Pregnancy Among Women Who Perform Regular Resistance Training: A Qualitative Study. Physical Therapy. 2014;94(8):1135-43. PubMed PMID: 2012669650. Language: English. Entry Date: 20140815. Revision Date: 20140829. Publication Type: journal article.

5. Lin YH, Tsai EM, Chan TF, Chou FH, Lin YL. Health promoting lifestyles and related factors in pregnant women. Chang Gung medical journal. 2009 Nov-Dec;32(6):650-61. PubMed PMID: 20035645. Epub 2009/12/29. eng.

6. Pauleta JR, Pereira NM, Graça LM. Sexuality During Pregnancy. The Journal of Sexual Medicine. 2010;7(1pt1):136-42.

7. Coutinho EC, Parreira MVBC. (2011). Outra forma de olhar de olhar a mãe imigrante numa situação de transição [Another way to look at the immigrant mother in a transition situation]. Millenium 2011; 40: 83-97.

8. Koletzko B, Bauer CP, Bung P, Cremer M, Flothkotter M, Hellmers $C$, et al. German national consensus recommendations on nutrition and lifestyle in pregnancy by the 'Healthy Start - Young Family Network'. Annals of nutrition \& metabolism. 2013;63(4):31122. PubMed PMID: 24514069. Epub 2014/02/12. eng.

9. Geddes L. Exercise during pregnancy boosts baby brain development. New Scientist. 2013 11/16/;220(2943):10

10. Briggs GG, Freeman RK, Yaffe SJ. Drugs in Pregnancy and Lactation: A Reference Guide to Fetal and Neonatal Risk. 9th ed. Philadelphia: Lippincott Williams \& Wilkins; 2011.
We hope that this study may contribute to understanding the Portuguese and immigrant women who experience the process of motherhood, in regard to the changes occurring in their lifestyles.

\section{ACKNOWLEDGEMENTS}

Portuguese Foundation for Science and Technology, through project PEst-OE/CED/UI4016/2014, and Centro de Estudos em Educação Tecnologia e Saúde (CI\&DETS).
11. Coutinho T, Monteiro MFG, Sayd JD, Teixeira MTB, Coutinho CM, Coutinho LM. Monitoramento do processo de assistência pré-natal entre as usuárias do Sistema Único de Saúde em município do Sudeste brasileiro. Revista Brasileira de Ginecologia e Obstetrícia. 2010;32:563-9.

12. Motozawa $\mathrm{Y}$, Hitosugi M, Abe T, Tokudome S. Effects of seat belts worn by pregnant drivers during low-impact collisions. American Journal of Obstetrics and Gynecology. 2010 7//;203(1):62.e1-.e8.

13. Silva, L. J., \& Silva, L. R. Mudanças na Vida e no Corpo: Vivências Diante da Gravidez na Perspectiva Afetiva dos Pais. Revista de Enfermagem Esc Anna Nery, 2009, Abril-Junho. http://www.scielo.br/pdf/ean/v13n2/v13n2a22.pdf

14. Akincigil A, Munch S, Niemczyk KC. Predictors of Maternal Depression in the First Year Postpartum: Marital Status and Mediating Role of Relationship Quality. Social Work in Health Care. 2010 2010/03/15;49(3):227-44.

15. Palmer K, Bonzini M, Ellekilde P. Pregnancy: Occupational Aspects Of Management: Concise Guidance. Royal College Of Physicians Clinical Medicine. 2013;13(1):75-9.

16. Bogaerts AFL, Devlieger R, Nuyts E, Witters I, Gyselaers W, Van den Bergh BRH. Effects of lifestyle intervention in obese pregnant women on gestational weight gain and mental health: a randomized controlled trial. Int J Obes. 2013 06//print;37(6):814-21.

17. Magalhães, L., Soares, R., Oliveira, S., \& Ribeiro, S. Sexualidade na gravidez. Revista Ecos da Enfermagem, 2007, №262.

18. Barbosa, B. N., Gondim, A. N. C., Pacheco, J. S., Pitombeira, H. C. S., Gomes, L. F., Vieira, L. F., \& BDamasceno, A. K. C. Sexualidade vivenciada na gestação: conhecendo essa realidade. Revista Eletrônica de Enfermagem, 2011. http://www. fen.ufg.br/revista/v13/n3/pdf/v13n3a12.pdf

19. Shapiro AF, Gottman JM, Carrére $S$. The baby and the marriage: Identifying factors that buffer against decline in marital satisfaction after the first baby arrives. Journal of Family Psychology. 2000;14(1):59-70. 